\title{
Independent endpoint event review for the elimination of reporting bias in an open label phase III pharmaceutical trial
}

\author{
Peter Hall ${ }^{1,2^{*}}$, Anna Waterhouse ${ }^{2}$, Isabelle Smith², Julia Brown ${ }^{2}$, Walter Gregory ${ }^{2}$, Guenther Steger ${ }^{4}$, Richard Bell ${ }^{3}$, \\ David Cameron ${ }^{1}$
}

From 3rd International Clinical Trials Methodology Conference

Glasgow, UK. 16-17 November 2015

\section{Background}

Open label randomised controlled trials may be subject to bias where outcome ascertainment relies on treating clinician decisions. In the setting of a multinational randomised controlled open label phase three pharmaceutical trial we implemented a rigorous verification algorithm to mitigate against such bias. We report the impact of the algorithm's application on the primary endpoint.

\section{Method}

The BEATRICE trial recruited 2591 patients with early surgically treated triple negative breast cancer from 360 sites in 37 countries into a two way randomisation. The primary endpoint was investigator reported invasive disease free survival (IDFS). A novel rigorous 103-step endpoint review algorithm was developed to provide central ratification in support of, but not mandating locally reported events.

\section{Results}

IDFS events were reported in 393 patients. There was no statistically significant difference between the arms. The HR was 0.88 [95\% CI $0.72-1.07]$ prior to algorithm application compared with 0.87 [95\% CI 0.72-1.07]. 393 events, the algorithm input changed dates in $74(19 \%)$, type of event in $7(2 \%)$ and site of event in $11(3 \%)$. The event number did not change.

\section{Conclusion}

Reassuringly the primary results of this open label RCT did not change with enhanced independent interrogation

University of Edinburgh, Edinburgh, UK

Full list of author information is available at the end of the article and review of reported endpoints. Current standard trial reporting procedures appear to be adequate even in the open label setting.

\section{Authors' details}

${ }^{1}$ University of Edinburgh, Edinburgh, UK. ${ }^{2}$ University of Leeds, Leeds, UK. ${ }^{3}$ Andrew Love Cancer Centre, Victoria, Australia. ${ }^{4}$ Medical University of Vienna, Vienna, Austria.

Published: 16 November 2015

\section{doi:10.1186/1745-6215-16-S2-P188}

Cite this article as: Hall et al:: Independent endpoint event review for the elimination of reporting bias in an open label phase III pharmaceutical trial. Trials 2015 16(Suppl 2):P188.
Submit your next manuscript to BioMed Central and take full advantage of:

- Convenient online submission

- Thorough peer review

- No space constraints or color figure charges

- Immediate publication on acceptance

- Inclusion in PubMed, CAS, Scopus and Google Scholar

- Research which is freely available for redistribution
() Biomed Central 